IZA DP No. 9554

The Impact of Teacher Demographic Representation on Student Attendance and Suspensions

Stephen B. Holt

Seth Gershenson

December 2015 


\title{
The Impact of Teacher Demographic Representation on Student Attendance and Suspensions
}

\author{
Stephen B. Holt \\ American University \\ Seth Gershenson \\ American University \\ and IZA
}

\section{Discussion Paper No. 9554 \\ December 2015}

\author{
IZA \\ P.O. Box 7240 \\ 53072 Bonn \\ Germany \\ Phone: +49-228-3894-0 \\ Fax: +49-228-3894-180 \\ E-mail: iza@iza.org
}

Any opinions expressed here are those of the author(s) and not those of IZA. Research published in this series may include views on policy, but the institute itself takes no institutional policy positions. The IZA research network is committed to the IZA Guiding Principles of Research Integrity.

The Institute for the Study of Labor (IZA) in Bonn is a local and virtual international research center and a place of communication between science, politics and business. IZA is an independent nonprofit organization supported by Deutsche Post Foundation. The center is associated with the University of Bonn and offers a stimulating research environment through its international network, workshops and conferences, data service, project support, research visits and doctoral program. IZA engages in (i) original and internationally competitive research in all fields of labor economics, (ii) development of policy concepts, and (iii) dissemination of research results and concepts to the interested public.

IZA Discussion Papers often represent preliminary work and are circulated to encourage discussion. Citation of such a paper should account for its provisional character. A revised version may be available directly from the author. 
IZA Discussion Paper No. 9554

December 2015

\section{ABSTRACT \\ The Impact of Teacher Demographic Representation on Student Attendance and Suspensions}

Representative bureaucracy theory is central to public administration scholarship due to the likely relationship between the demographic composition of the public workforce and both the actual and perceived performance of public organizations. Primary school classrooms provide an ideal context in which to test the predictions of representative bureaucracy theory at the micro (student) level. Specifically, since parents have at least some agency over primary school students' daily attendance, absences reflect parental assessments of their child's school, classroom, and teacher. The representativeness of the teacher workforce, and specifically that of the student's classroom teacher, is therefore likely to influence student absenteeism. Similarly, student suspensions reflect students' relationships with their teacher, students' comfort level in the classroom, and teachers' discretion in the referral of misbehavior. These academically and socially important outcomes provide convenient, objective measures of behaviors that are likely influenced by street-level representation. Using longitudinal student-level administrative data from the North Carolina, we use a twoway (student and classroom) fixed effects strategy to identify the impact of student-teacher demographic mismatch on primary school students' absences and suspensions. We find that representation among street-level bureaucrats significantly decreases both absenteeism and suspensions and that these effects can be given a causal interpretation. The introduction of two-way fixed effects estimators to public administration scholarship is a secondary contribution of the current study.

JEL Classification: $\quad 12$

Keywords: representative bureaucracy, student absences, elementary education, teacher workforce

Corresponding author:

Seth Gershenson

School of Public Affairs

American University

4400 Massachusetts Avenue, NW

Washington DC, 20016-8070

USA

E-mail: gershens@american.edu 


\section{Introduction}

Student absences disrupt classrooms and, as a result, have received a great deal of attention from educators, researchers, and policymakers. Research shows that student absences reduce academic achievement (e.g., Aucejo \& Romano 2014; Goodman 2014; Gottfried 2009) and put students at risk for future truancy (e.g., Rumberger 1995; Ensminger \& Slusarcick 1992; Alexander et al. 1997). In addition to the policy-relevant impact of absences on student achievement and attainment, absences in elementary school may also provide a marker of parents' assessments of a school's or teacher's effectiveness, since parents have at least some agency over young children's attendance (Morrissey et al. 2014). Students who are suspended from school early in their academic lives, particularly via out-of-school suspensions (OSS), show similar patterns of increased truancy and lower academic achievement (Costenbader \& Markson 1998; Mendez et al. 2002; Mendez 2003; Arcia 2006). In addition to falling behind academically, students who are absent and suspended may become alienated from their classmates and teachers in ways that cause them to further disengage from school (Finn 1989). The combination of primary school absences, early suspensions, and academic disengagement increases the probability that students fail to complete high school (Rumberger 1995; Alexander et al. 1997; Mendez et al. 2002).

Understanding the determinants of student absences and suspensions is crucial for policymakers and educators seeking to improve student outcomes, particularly for traditionally disadvantaged students. However, while the consequences of student absences and suspensions are fairly well established, less attention has been given to the determinants of absences and suspensions (Morrissey et al. 2014; Kinsler 2011). Teachers are street-level bureaucrats who serve as the contact point between families and schools, and exercise a great deal of discretion 
that plays an important role in the educational process (Pitts 2007). The relationship between teachers, school staff, and families can have large effects on student absenteeism (Epstein \& Sheldon 2002). Representative bureaucracy theory, which examines the relationships between the sociodemographic composition of public agencies, public employees' behaviors, and public employees' reception by the public they govern (Grissom 2015; Mosher 1968; Krislov 1974), may therefore provide some insight into how the representativeness of the teacher workforce influences primary school students' attendance and behavior.

The current study examines primary school student absences and suspensions through the lens of representative bureaucracy theory. Specifically, we test a central prediction of representative bureaucracy theory-that demographic representation among street-level bureaucrats affects performance in public organizations through public and street-level bureaucrat responsiveness to demographic alignment-by testing the hypotheses that studentteacher racial mismatch affects individual students' absences and suspensions. In doing so, we make several contributions to the extant representative bureaucracy literature, which generally documents a strong relationship between district-level demographic representation among teachers and student achievement (e.g., Meier \& Stewart 1992; Meier 1993; Pitts 2007). First, we introduce two-way fixed effects estimators, which are a relatively recent development in labor economics (e.g., Abowd \& Kramarz 1999), to the field of public management. This approach is useful in that it can frequently identify causal estimates in observational studies by simultaneously controlling for multiple sources or dimensions of unobserved heterogeneity (omitted variables) and has many potential applications in public management research. For example, simultaneously controlling for employee and agency fixed effects that control for unobserved, time-invariant individual characteristics that affect sorting into agencies and agency- 
specific cultures and missions, respectively, would potentially facilitate the estimation of causal effects of management initiatives and other interventions on public employee motivation, performance, and turnover. Second, we are one of the first studies to use student-level data to study representative bureaucracy in the context of education, which reduces concerns about potential aggregation bias (Burstein 1980; Hanushek, Rivkin, \& Taylor 1996) and provides further evidence on the robustness of previous analyses conducted at the school (Keiser et al. 2002) and district (Meier \& Stewart 1992; Meier 1993; Pitts 2007) levels. Finally, and perhaps most importantly, we test the implications of representative bureaucracy theory in the school setting using a novel outcome: student attendance. Student attendance is a useful outcome in this context because, in addition to established links between attendance and achievement, attendance in elementary school partly reflects parents' assessments of their child's school and their relationship with their child's teacher. Using data on student attendance allows us to investigate the mechanisms through which representation affects public organization performance suggested by representative bureaucracy theory, such as perceived legitimacy and public support (Krislov 1974; Riccucci et al. 2014), by examining households' responses to racially mismatched teachers.

The current study relies on longitudinal administrative data on all primary school (grades K-5) students and teachers in North Carolina's public schools between the 2006 and 2010 academic years. ${ }^{1}$ Causal effects of student-teacher racial mismatch on student outcomes are identified via a two-way student and classroom fixed effects (FE) strategy (e.g., Fairlie, Hoffman, \& Oreopoulos 2014) that is novel to the field of public administration and can likely

${ }^{1}$ Throughout the manuscript, academic years are referred to by the calendar year of the spring semester (e.g., 2006 refers to the 2005-2006 academic year). We analyze these years because these are the years for which student absences, our key dependent variable, are available. 
be fruitfully applied to numerous other questions in the discipline. The main results indicate that students assigned to an other-race teacher have significantly more absences and suspensions, and are more likely to be chronically absent and to be suspended at least once, than their counterparts who were assigned to a same-race teacher. These effects are slightly larger for male students, and particularly non-white male students, though these differences are rarely statistically significant. A "sorting test" suggests that these results are unlikely to be driven by nonrandom sorting of students to other-race teachers, further supporting a causal interpretation of the main results. Together, these results provide robust support for the prediction of representative bureaucracy theory that representation can directly affect the relationship between street-level bureaucrats and the public they serve in nuanced ways.

Prior research on demographic mismatch and representative bureaucracy in the education context uses test scores and punishments to make inferences about the relationship between mismatch, student and teacher interactions, and effort in the classroom. However, in addition to hypothesizing about how representation directly affects performance, representative bureaucracy theory also suggests that more representative public organizations will engender broader public support. Absenteeism in elementary school at least partially reflects the relationship between parents, teachers, and students: when parents view their child's school and teacher positively, they invest more effort in facilitating regular school attendance. Using absenteeism as a novel measure of public behavioral response to representation among street-level bureaucrats in schools, we show that, in the context of education, representation and public support are positively linked and serve as a mechanism through which representation affects performance.

The next section summarizes the literature on representative bureaucracy theory, studentteacher racial mismatch, and student absences and suspensions. Drawing on these literatures, the 
following sections specify our hypotheses about the relationship between representation and absences and suspensions, and the data and methods we use to test them. Finally, we offer some concluding remarks and discuss the implications of these findings.

\section{Literature Review and Theoretical Framework}

\section{Representative Bureaucracy Theory}

First postulated by Kingsley (1944), representative bureaucracy theory has received a great deal of attention from public administration scholars. Dolan and Rosenbloom (2003) and Keiser (2011) provide general reviews of the literature. The review by Grissom et al. (2015) focuses specifically on representative bureaucracy theory's implications for research on education policy and practice. Since Kingsley (1944), representative bureaucracy theory has evolved to explicitly draw empirically testable links between the representativeness of a given bureaucracy and policy outputs from the bureaucracy itself (e.g., Long 1952; Van Riper 1958).

Mosher (1968) distinguished between passive representation (i.e., the degree of demographic match between a bureaucracy and its constituents) and active representation (i.e., the degree to which a bureaucrat exercises discretionary authority to directly benefit the demographic group with which the bureaucrat most closely identifies). Further, Mosher argued that passive representation can provide important symbolic signaling that legitimizes bureaucrats' decision-making authority. Others have suggested that passive representation is more likely to transition into active representation as a particular subgroup's proportion increases within an organization (Krislov 1974; Meier 1975; Rosenbloom \& Featherstonhaugh 1976). More recently, scholars have suggested that active representation is more likely when an organization's actions can benefit the standing of a specific underrepresented or disadvantaged 
subgroup (e.g., the provision of education) (Thompson 1976; Selden 1997; Meier \& Stewart 1992; Keiser et al. 2002).

Of particular relevance to the current study are the symbolic effects of the representativeness of the public workforce on citizen interactions with government officials. Specifically, representative bureaucracy theory postulates that a more demographically representative bureaucracy sends symbolic signals of equal opportunity for social advancement. Such symbolic effects could in turn lend legitimacy to, and acceptance of, bureaucratic decisions (Krislov 1974; Theobald \& Haider-Markel 2009; Gade \& Wilkins 2013; Riccucci et al. 2014). The link between symbolic representation and public trust in public organizations has been empirically tested in a variety of contexts. For instance, Marschall and Ruhil (2007) found that African-American citizens had more positive views of public services in cities where AfricanAmericans had greater representation in city hall and on school boards. Meier and NicholsonCrotty (2006) found that police forces with more female officers received more reports of sexual assault and made more arrests related to sexual assault crimes (see also Riccucci et al. 2014). Theobald and Haider-Markel (2009) also examined police officers and found that respondents are more likely to view police sanctions as legitimate if a same-race officer is present during the incident (see also Wilkins \& Williams 2008, 2009). These findings suggest a reciprocal relationship between passive and active representation at the street-level of public organizations. When public servants look like the citizens they represent, citizens' trust in public services increases and public servants are more responsive to citizens' concerns.

In the context of education, several studies suggest that the representativeness of the teacher workforce creates both symbolic and active representation. Meier and Stewart (1992) used data from Florida to test whether black students in districts with more representative teacher 
workforces experienced different rates of tracking, suspensions and expulsions, and academic achievement. The authors found that an increase in the proportion of black teachers in the district led to fewer severe disciplinary actions, more tracking into gifted programs, and higher achievement for black students. These results suggest a positive correlation between passive and active representation. Similarly, Keiser et al. (2002) used data on Texas school districts that contained a single high school to examine the relationship between student-teacher gender congruence and student achievement. Consistent with results from the education literature on student-teacher demographic mismatch (e.g., Dee 2004, 2007; Clotfelter, Ladd, \& Vigdor 2006; Egalite et al. 2015), the authors found a positive relationship between a school's proportion of math teachers who are female and female students' performance on math standardized tests.

The evidence described above documents a clear association between demographic representation and student achievement, and similarly for the preponderance of academic tracking, suspensions, and expulsions. The relationship between street-level bureaucrats and the public they serve may be a mechanism through which representation affects performance. In the context of primary schools, the relationship between teachers, parents, and students likely shapes student absenteeism. We introduce student absenteeism as a novel measure of teacher relationships with the families they serve.

\section{Absences}

Since parents have at least some control over primary school students' attendance, parents' attitudes and beliefs about education likely affect student absenteeism in elementary school (Alexander et al. 1997; Morrissey et al. 2014). For example, Ready (2010) finds that household socioeconomic status, as measured by an index of parents' income, educational 
attainment, and occupational prestige, is negatively associated with student absences in the nationally representative Early Childhood Longitudinal Study - Kindergarten Cohort (ECLS-K). Similarly, children in low-income households and the children of young mothers are more likely to be chronically absent than their more advantaged counterparts (Romero \& Lee 2008; NCES 2006). Moreover, a disproportionate share of the absences of low-income students and students with behavioral problems are unexcused absences (Gottfried 2009). Together, these descriptive patterns suggest that household characteristics influence student absences and that at least some student absences are discretionary.

Factors outside the household may influence student attendance as well. It is generally agreed that teachers have the largest impacts on students' academic achievement of all schoolprovided inputs (e.g., Rivkin, Hanushek, \& Kain 2005; Hanushek \& Rivkin 2009). However, teachers likely influence students' non-cognitive development, behavior, and attitudes towards education as well. Regular attendance is one objective, easily observable manifestation of noncognitive (i.e., "soft”) skills (Gershenson 2015; Jacob 2002; Jackson 2013). Specifically, teachers might influence student attendance by promoting student engagement, creating a sense of community in the classroom, and directly imparting the importance of regular attendance (Baker et al. 2010; Kelly 2012; Ladd \& Sorensen 2014; Monk \& Ibrahim 1984). Particularly in the primary school context, teachers may actively contact parents to either proactively or reactively address attendance concerns (Sheats \& Dunkleberger 1979; Epstein and Sheldon 2002). A growing body of evidence supports these hypotheses: Ladd and Sorenson (2014) and Gershenson (2015) show that primary and middle school teachers in North Carolina affect student attendance and Jackson (2013) shows that ninth grade teachers in North Carolina affect a “non-cognitive skill index," of which student absences are an element. Similarly, Jennings and 
DiPrete (2010) show that kindergarten and first grade teachers in the nationally representative ECLS-K affect an index of socio-emotional skills. However, while these studies provide evidence of arguably causal effects of teachers on student attendance (and related "soft" skills), they stop short of identifying the precise mechanisms through which such effects operate. Representative bureaucracy theory suggests that demographic representation among street-level bureaucrats improves the relationship between street-level bureaucrats and citizens. Thus representation among the teacher workforce, specifically student-teacher demographic match, may be one mechanism through which teachers affect student attendance.

\section{Suspensions}

Black students receive suspensions, particularly out-of-school suspensions (OSS), at higher rates than their white peers (Skiba et al. 2002; Mendez et al. 2002; Losen \& Skiba 2010; U.S. Department of Education, 2014). Moreover, black students frequently receive longer suspensions for the same type of infraction than their white peers (Kinsler 2011; Skiba et al. 2014). Black students also disproportionately receive classroom referrals for suspension, indicating that classroom environments may influence both the frequency and duration of suspensions (Bradshaw et al. 2010; Rocque 2010). These patterns highlight the fact that, unlike student absences, teachers and principals have discretion in both whether, and how severely, to impose suspensions as a disciplinary tool. Indeed, the use of suspensions has increased over time (Losen \& Skiba 2010) and the types of rule infractions for which students are suspended have grown over time to include disruptions of daily class activities (Gregory \& Weinstein 2008; Gregory et al. 2010; Skiba et al. 2011). 
A small but growing literature investigates the schooling inputs and interventions that affect student suspensions. For example, Figlio (2006) presents evidence that Florida schools responded to the passage of a test-based accountability policy by suspending suspected lowscorers during the week of the high stakes test. Particularly relevant to the current study, the noncognitive skill index studied by Jackson (2013) is based in part on student suspensions, and again Jackson finds significant variation in teachers' effects on students' non-cognitive skills, as measured by this index. Similarly, Kinsler (2011) investigates potential sources of racial disparities in the frequency and length of suspensions in North Carolina and finds that such disparities are largely driven by variation between, rather than within, schools. The author then begins to investigate the relationship between student-teacher racial mismatch and suspensions, but does not fully address the likely endogenous assignment of students to teachers. Guided by the predictions of representative bureaucracy theory and the two-way fixed effects empirical strategy of Fairlie et al. (2014), the current study extends the work of Kinsler (2011) by documenting the causal relationship between student-teacher racial mismatch and suspensions on both the intensive and extensive margins, as well as testing for heterogeneity in such relationships by student race and gender.

There are several reasons, many of which are motivated by representative bureaucracy theory, to expect that student-teacher racial mismatch might affect student suspensions. Indeed, research finds evidence of effects of student-teacher demographic mismatch on teacher behaviors in a variety of contexts. Same-race and same-gender teachers provide better feedback on assignments (Casteel 1998) and hold more positive subjective assessments of student ability, attentiveness, and effort (Dee 2005; Ouazad 2014; Cornwell et al. 2013). Similarly, same-race secondary school teachers have higher expectations for black students' educational attainment 
than do white teachers (Gershenson, Holt, \& Papageorge 2015). Demographically matched teachers also have more frequent positive individual interactions with students (Meier et al. 1989; Casteel 1998). Together, these studies provide examples of active representation in the classroom and suggest that teachers' more positive dispositions towards same-race students might induce better behavior from same-race students and result in more lenient punishments for same-race students.

A related stream of research in the economics of education routinely finds evidence of a causal relationship between student-teacher demographic mismatch and student achievement in the primary, secondary, and post-secondary contexts (e.g., Dee 2004, 2007; Clotfelter, Ladd, \& Vigdor 2006; Egalite et al. 2015; Fairlie, Hoffman, \& Oreopolous 2014; Hoffman \& Oreopolous 2009; Burgess \& Greaves 2013; Ehrenberg \& Brewer 1994). While some of these effects are potentially attributable to teachers actively aiding race- or gender-congruent students, symbolic effects of passive representation likely contribute as well. In the education literature, such symbolic effects are sometimes referred to as role-model effects and stereotype threat. For example, if white teachers have low expectations for black students, they may modify how they teach, evaluate, and advise black students in ways that lead to poor socio-behavioral outcomes (e.g., suspensions and absences) (Ferguson 2003). Similarly, if black students perceive that white teachers have low expectations for them, this might exacerbate the harmful effects of stereotype threat and ultimately cause students to dis-identify with educational environments (Steele 1997). Such dis-identification or dis-engagement with formal schooling might manifest in increased rates of student absences and suspensions.

While previous work in the representative bureaucracy literature highlights the role that representation likely plays in the educational process, the extant literature's empirical analyses 
are conducted at the school or school-district level. This is potentially problematic, as aggregated student outcomes, such as test scores or punishments, reflect both individual- and group-level processes, introducing potential aggregation bias into estimates using district-level data (Burstein 1980; Hanushek, Rivkin, \& Taylor 1996). Disentangling group-level and individual-level effects is essential to establishing a causal link between bureaucratic representativeness and behavioral responses among the public. Moreover, teachers and students likely sort into schools and classrooms in a non-random fashion; studies that fail to account for such endogenous sorting are unlikely to identify the causal relationships that would provide definitive evidence of the behaviors predicted by representative bureaucracy theory. In other words, relationships between the demographic composition of a district's teacher force and the outcomes of demographically similar students in that district may be attributable to something other than representation (Clotfelter, Ladd, \& Vigdor 2005, 2006; Clotfelter et al. 2006; Guarino et al. 2014). Bradbury and Kellough (2010) note the need for micro-level estimates of the impacts of demographic mismatch between bureaucrats and the citizens they serve on behavioral and policy outcomes in order to better establish causation. Toward that end, the current study makes a variety of contributions to the representative bureaucracy literature. First, we employ student and teacher (micro) level data to examine individual-level effects of demographic representation among teachers on student outcomes. Second, we introduce a novel empirical strategy for identifying unbiased estimates of the causal effects of demographic representation on students. Using twoway fixed-effects models that account for both student and teacher unobserved heterogeneity, we identify the causal relationship between demographic representation and student outcomes. Finally, we link education policy scholarship on absences and representative bureaucracy 
scholarship to identify street-level demographic representation as a mechanism through which teachers and schools influence student attendance.

\section{Hypotheses}

The current study tests the following hypotheses derived from representative bureaucracy in the context of elementary education.

H1: Students assigned to an other-race teacher have more absences, more unexcused absences, and are more likely to be chronically absent.

As noted above, teachers may more actively support students of the same race. This may be through higher subjective assessments of ability and educational expectations (Gershenson et al. 2015; Ouazad 2014; Meier \& Stewart 1992) or higher effort on the part of teachers (Keiser et al. 2002; Meier \& Stewart 1992). Alternatively, absenteeism may be caused by parental and student discomfort with other-race teachers through symbolic effects of demographic representation. We do not disentangle the effects of active and passive representation, though systematic differences in absences between the students of same-race and other-race teachers likely reflects behavioral responses to both active and passive representation.

H2: Students assigned to an other-race teacher have more suspensions and are more likely to ever be suspended.

Despite a large body of evidence indicating that African-American students are referred to suspension more often and are more likely to receive longer suspensions than their white counterparts (e.g., Gregory 1995; U.S. Department of Education 2014), the mechanisms driving this relationship remain unclear (Kinsler 2011). If representation plays a role in referring students to suspension, students paired with racially mismatched teachers will be more likely to be suspended and to receive more suspensions. 


\section{Data}

The empirical analysis uses student-level longitudinal administrative data on kindergarten through fifth grade students in North Carolina's public schools between 2006 and 2010 to test the hypothesis that public behavior responds to demographic representation among street-level bureaucrats. The data were coded and made available to researchers by the North Carolina Education Research Data Center (NCERDC). The NCERDC student-level records from these years can be linked to unique classroom teacher identifiers via course membership files. The data also contain information on student and teacher demographics (i.e., race and sex) and annual tallies of students' total absences, excused and unexcused absences, and total suspensions. Restricting the analytic sample to students in self-contained K-5 classrooms for whom student absences and basic student and teacher demographic information is observed yields a sample of $1,028,885$ unique students, 43,708 unique teachers, 162,209 unique classrooms, and 2,124,022 student-year observations. Student-years are the unit of analysis. Suspension data and the distinction between excused and unexcused absences are sometimes missing, usually in concert and at the school level.

\section{Dependent variables}

The primary dependent variable of interest is the count of annual total absences. When possible, we also decompose total absences into excused and unexcused absences. Unexcused absences are of particular interest, as teachers and schools likely have larger effects on unexcused absences and unexcused absences cause more harm to student achievement than do excused absences (Gottfried 2009). Of course, focusing on average changes in annual absences may mask important distributional effects of student-teacher racial mismatch on absenteeism. 
For instance, a classroom taught by a black teacher in which most black students exhibit no change in annual absences and a handful of black students experience a large increase in attendance would yield a deceptively small estimated effect of having a same-race teacher on student absenteeism. To avoid such concerns, we also estimate models of chronic absenteeism, where chronic absence is defined as being absent 18 or more times during the academic year. ${ }^{2}$ These are implemented as binary outcome models in which the dependent variable equals one if the student was absent 18 times or more and zero otherwise.

We also examine the effect of student-teacher demographic mismatch on total suspensions. Unlike absences, even one suspension is a major shock and many students complete entire academic years, and even entire primary school careers, without experiencing even one suspension. Accordingly, we also consider an "ever suspended" outcome, which is simply a binary indicator equal to one if the student was suspended at least once during the academic year, and zero otherwise.

\section{Independent variables}

The independent variable of interest is a measure of the racial match between student and teacher. We operationalize this by creating an other-race indicator that equals one if the student's race is different from the teacher's race, and zero if the student and teacher are of the same race. The other-race indicator can then be interacted with student race and gender indicators to test whether the effect of having an other-race teacher varies by students' demographic backgrounds.

\footnotetext{
2 Definitions of "chronically absent" vary, but the modal definition is being absent on at least 10 percent of school days (18 absences per year in a standard 180 day tear) (Balfanz and Byrnes 2012; Bruner, Discher, and Chang 2011).
} 


\section{Descriptive Statistics}

Table 1 summarizes the analytic sample. Column 1 does so for the full sample and shows that on average, students were absent about seven times per year and about 6 percent of students were chronically absent per year. On average, about 60 percent of absences were unexcused. As expected, suspensions are quite rare among primary school students: only about 3 percent of students were ever suspended in a given year. About 40 percent of students had an other-race teacher. The student population is slightly more than half white, one quarter black, and about eleven percent Hispanic.

Columns 2-5 of table 1 similarly summarize the analytic sample separately for white, nonwhite, male, and female students, respectively. Consistent with previous research, a simple comparison of columns 2 and 3 shows that nonwhite students are significantly more likely to be suspended, and have more suspensions, than white students (e.g., Kinsler 2011). Nonwhite students are also significantly more likely to have an other-race teacher than are white students, as the overwhelming majority of primary school teachers in North Carolina are white females. This is true in nationally representative survey data as well (Gershenson et al. 2015). Also consistent with past research, a simple comparison of columns 4 and 5 shows that male students are significantly more likely than female students to be suspended (e.g., Costenbader \& Markson 1998; Skiba et al. 2002; Mendez \& Knoff 2003). However, males and females are equally likely to be assigned to an other-race teacher, which is again consistent with patterns in nationally representative survey data (Gershenson et al. 2015).

Table 2 presents OLS estimates of descriptive regressions that further examine differences between demographic subgroups in the likelihood of being assigned to an other-race teacher and in absences and suspensions. Panel A uses crude white/nonwhite race categories 
while panel B uses six specific race categories. Column 1 confirms that nonwhite students are significantly more likely than white students to have an other-race teacher and that this is true for all racial minorities. Panel A of column 2 shows that males have slightly more absences than females, and that nonwhite students have almost one fewer absence per year than white students.

Panel B of column 2 reveals substantial heterogeneity in annual absences across nonwhite races. Specifically, the lower absence rate for non-white students seen in panel A is driven primarily by Asian students, who on average are absent two fewer times than white students. Black students, meanwhile, average 1.2 more absences per year than white students. Column 3 documents similar patterns in the probability of being chronically absent. Columns 4 and 5 of table 2 do the same for total suspensions and "ever suspended", respectively. Once again, the demographic patterns in suspensions are similar to those documented in previous research and to those for absences documented in columns 2 and 3 of table 2. Specifically, boys have significantly more suspensions, and are significantly more likely to have ever been suspended, than girls. Nonwhites are significantly more likely to have been suspended than white students, and this is driven by both black and Hispanic students. Asian students experience significantly fewer suspensions than white students.

\section{Method}

The goal of the current study is to estimate the causal effect of student-teacher racial mismatch on student outcomes $(Y)$ such as absences and suspensions. Intuitively, then, interest is in the $\delta$ parameter in student-year multivariate regression models of the form

$$
Y_{i j s t}=\beta_{0}+\beta_{1} \text { race }_{i}+\beta_{2} \text { race }_{j}+\delta 1\left\{\text { race }_{i} \neq \text { race }_{j}\right\}+\beta_{3} X_{i}+\beta_{4} Z_{j s t}+\varepsilon_{i j s t},
$$

where subscripts $i, j, s$, and $t$ index students, teachers, schools, and years, respectively; race is a set of mutually exclusive race indicators; $1\{\cdot\}$ is an indicator function; $X$ is a vector of time- 
invariant student characteristics (e.g., gender, innate ability); $Z$ is a vector of time-varying teacher and school characteristics (e.g., teacher's experience, certification, class size; school's enrollment, resources, principal effectiveness); and $\varepsilon$ is an idiosyncratic error term comprised of unobserved determinants of $Y .^{3}$

Of course, OLS estimates of equation (1) are very likely biased by unobserved factors that jointly determine assignment to an other-race teacher and outcomes $Y$. For example, parental motivation and involvement in children's education likely influences both student attendance and classroom assignments. Accordingly, we follow Fairlie et al. (2014) in augmenting equation (1) to include both student and classroom fixed effects (FE). Equation (1) becomes

$$
Y_{i c}=\delta 1\left\{\text { race }_{i} \neq \text { race }_{c}\right\}+\theta_{i}+\omega_{c}+\varepsilon_{i c},
$$

as student race and $X$ are subsumed by the student $\mathrm{FE}(\theta)$; teacher race and $Z$ are subsumed by the classroom FE $(\omega)$; and the $j, s, t$ subscripts collapse to a single classroom subscript $(c)$ since the sample is restricted to students in self-contained classrooms.

Simultaneously controlling for student and classroom FE is crucial to the identification strategy. The student FE ensure that $\delta$ is identified from within-student variation in "other race" (i.e., students who have an other-race teacher in some years but not others) and thus control for potentially confounding student or household factors that jointly influence student outcomes and assignment to an other-race teacher. Similarly, the classroom FE ensure that $\delta$ is identified from within-classroom variation in "other race" (i.e., comparing students of different races in the same classroom, some who are the same race as the classroom teacher and some who are not). Since teacher FE are subsumed by the classroom FE, classroom FE effectively control for the

${ }^{3}$ Of course, $X$ could be allowed to be time-varying as well, and include things like lagged test scores or lagged dependent variables. Doing so does yields estimates that are qualitatively similar, and often nearly identical, to the preferred student fixed effects estimates. 
possibility that nonwhite teachers have different attitudes towards student discipline than do white teachers. The classroom FE also ensure that comparisons are made between white and nonwhite students who are subject to the same classroom resources, disruptions, and instructional quality and philosophy. Estimating the two-way FE specification in equation (2) using the usual OLS estimator is computationally infeasible due to the high dimensionality of the model (i.e., 1,028,885 student FE and 162,209 classroom FE) (Abowd et al. 1999). We sidestep this problem by using the two-way FE estimation algorithm proposed by Mittag (2012). ${ }^{4}$ Standard errors are clustered by school, which makes statistical inference robust to the likely failure of iid between students and classrooms within the same school, and to the presence of serial correlation within schools over time.

The remaining threat to the validity of the two-way FE estimates is endogenous sorting that systematically varies by teacher and student background. Intuitively, the student FE control for the possibility that white and nonwhite students are systematically different, or that the students assigned to white teachers are systematically different from those assigned to nonwhite teachers. However, if such differences vary by student and teacher race, such differential sorting might bias the two-way FE estimates because the error term in equation (2) would be correlated with the "other race" indicator. An example of such differential sorting is the scenario in which black students with high unobserved ability sort into classrooms taught by black teachers while white students with high unobserved ability sort into classrooms taught by white teachers.

Following Fairlie et al. (2014), we test for the presence of this type of differential sorting on observables. Intuitively, if there is no systematic differential sorting on observable student

\footnotetext{
4 The estimation of multi-way FE models is an active area of research (e.g., Abowd et al., 2002; Arcidiacono et al., 2012; Correia, 2015; Gaure, 2013; Guimarães \& Portugal, 2010).
} 
characteristics $(L)$ and the elements of $L$ are highly correlated with the $\varepsilon$ in equation (2), then differential sorting on unobservables of the sort described above is unlikely to seriously threaten the validity of the preferred two-way student and classroom FE estimator given in equation (2).

Implementing a Fairlie et al. (2014) style test for differential sorting by observables requires computing the mean value of student characteristic $L$ of classroom $c$ 's race- $r$ students $\left(\bar{L}_{c}^{r}\right)$. In the simplest form of the test we create a binary indicator equal to one for the black student average, and zero for the non-black student average. We then use two observations per classroom to estimate linear regressions of the form

$$
\bar{L}_{c g s t}^{r}=\alpha \text { Black }_{c}+\gamma 1\{r=1\}+\pi \text { Black }_{c} \times 1\{r=1\}+\xi_{g}+\psi_{s}+\tau_{t}+e_{c g s t}^{r}
$$

where $c, g, s$, and $t$ index classrooms, grades, schools, and years, respectively; Black is a binary indicator equal to one if the classroom teacher is black, and zero otherwise; $1\{\cdot\}$ is an indicator function; $\xi, \psi$, and $\tau$ are grade, school, and year FE, respectively; and $e$ is an idiosyncratic error term. An alternative version of (3) is estimated in which the three FE are combined in one gradeby-school-by-year FE. Standard errors are clustered by schools.

The parameter of interest is $\pi$, which represents the "difference-in-differences estimate" of the average difference in observed characteristics between black and non-black students who are assigned to black and non-black teachers. Intuitively, if $\pi$ is significantly different from zero, there is differential sorting on observables by student race that varies with the race of the classroom teacher. If this is occurring, it is likely that similar sorting occurs on unobservables as well, which would bias estimates of the preferred two way FE model characterized by equation (2). Alternatively, if the OLS estimate of $\pi$ is statistically indistinguishable from zero, there is no evidence of differential sorting on observables, and thus differential sorting on unobservables in 
a way that would bias the two-way FE estimates of (2) is unlikely.

\section{Results}

\section{Sorting Test}

Table 3 reports estimates of the sorting test characterized by equation (3) for six observed student characteristics that are likely correlated with the $\varepsilon$ in equation (2): gender, lagged unexcused absences, lags of the "chronic absence" and "ever suspended" indicators, and administrative diagnoses of math and reading learning disabilities. Regardless of how the grade, school, and year FE are specified, table 3 shows that the interaction term is statistically indistinguishable from zero, and small in magnitude, for each of the six student characteristics. There is no evidence of endogenous sorting on student observables into classrooms taught by "other race" teachers; thus it is unlikely that such sorting occurs on unobservable dimensions.

\section{Effects of Racial Mismatch on Student Absences}

Table 4 presents estimates of the baseline two way FE specification for various measures of absenteeism. Column (1) uses a simple count of total annual absences and finds that being assigned to an other-race teacher leads to about 0.04 more absences per year, and this small effect is marginally statistically significant. Of course, focusing on the count of total annual absences might be misleading for at least two reasons. First, it could be that having an other-race teacher has a particularly strong effect on some students, but essentially zero effect on others. We investigate this hypothesis in column (2) by replacing the count of absences with a binary indicator equal to one if the student was chronically absent (18 or more absences), and zero otherwise. The estimated effect of having an other-race teacher on the probability of being 
chronically absent is 0.002 , which translates to a $3 \%$ increase, and is statistically significant at the $5 \%$ confidence level. This effect is perhaps practically significant as well, given that, after accounting for SES and initial skills, chronically absent students perform 14 percent worse in developing literacy skills in kindergarten than their counterparts with average absences (Ready 2010). Achievement gaps attributable to early chronic absenteeism only grow over time: by fourth grade, they account for about 17 percent of the achievement gap between white and nonwhite students (Musser 2011).

Second, unexcused absences are likely more malleable than excused absences with regards to schooling inputs and are therefore the type of student absence more likely to be influenced by teachers' representativeness. Accordingly, columns (3) and (4) of table 4 report estimates of two way FE models that take the annual counts of excused and unexcused student absences, respectively, as the dependent variable. Consistent with this reasoning, column (3) shows that there is essentially zero relationship between student-teacher racial match and students' excused absences, while column (4) shows that other-race teachers have a positive, statistically significant effect on unexcused absences of about 0.06 unexcused absences (2.3\%). That the effect is larger on unexcused absences is consistent with the hypothesis of representative bureaucracy theory that some combination of passive and active representation affects students' and parents' engagement with the school. This intuitive result also provides additional evidence that our empirical strategy is identifying a causal relationship.

The baseline estimates reported in table 4, which restrict the effects of student-teacher racial mismatch on student absences to be the same for all students, might mask important variation in such effects across the student body. Indeed, there are numerous reasons why such effects might vary by student demographics. For example, Gershenson et al. (2015) find that 
student-teacher demographic mismatch affects teachers' educational expectations for black students, and particularly for black males, but not for students from other racial backgrounds. More generally, effects of mismatch are likely greater for subgroups of the student population whose race and gender are underrepresented in the teacher workforce (Thompson, 1976; Meier \& Stewart, 1992; Grissom et al. 2015).

Accordingly, we test for heterogeneity in the causal relationship between student-teacher racial mismatch and student absences by augmenting equation (2) to include interactions between the other-race indicator and indicators of students' race and gender. Table 5 presents these estimates for three measures of absenteeism: total absences, chronic absence, and unexcused absences. The first 3 columns of table 5 sequentially allow the effect of having an other-race teacher to vary by student gender, student race, and student gender and race simultaneously. The male and nonwhite interaction terms are always positive, but never statistically significant, indicating that male, nonwhite, and particularly nonwhite male students' absences are more affected by having an other-race teacher, but not significantly so. The estimated effect for nonwhite males in column 3 of table 5 is particularly striking, as it is nearly three times larger than the baseline estimate in column 1 of table 4 , and indicates that nonwhite males assigned to white classroom teachers have an extra 0.11 annual absences (2\%).

Columns 4-6 of table 5 do the same for chronic absence, and find remarkably similar patterns: males, nonwhite students, and particularly nonwhite males are disproportionately affected by having an other-race classroom teacher. For example, the nonwhite males assigned to white teachers are 0.6 percentage points more likely to be chronically absent than nonwhite males assigned to a same-race teacher, and this difference is statistically significant at the $5 \%$ 
confidence level. This estimate is arguably practically significant as well, as it represents a ten percent increase in the likelihood that a student is chronically absent.

Finally, columns 7-9 of table 5 repeat the exercise for unexcused absences. These results are more mixed, as the nonwhite interaction terms are smaller in magnitude and sometimes negative, though once again none of the interaction terms are statistically significant. However, column 7 does show that boys' unexcused absences are more affected by having an other-race teacher than those of girls, which is consistent with the results for total absences and chronic absence observed in columns 1 and 4 of table 5.

\section{Effects of Racial Mismatch on Student Suspensions}

Table 6 analyzes the relationship between student-teacher racial mismatch and student suspensions in the same ways that student absences were investigated in tables 4 and 5. Similar patterns emerge: assignment to an other-race teacher increases students' propensity to be suspended and these effects are strongest among male and nonwhite students. Column 1 of table 6 presents baseline two-way FE estimates of the effect of student-teacher racial mismatch on the intensive margin of student suspensions, as measured by total annual suspensions. The estimate in column 1 shows that, on average, students with a racially mismatched teacher are suspended 0.01 more times per year than their counterparts with a race-congruent teacher. While this effect is modest in magnitude, recall that suspensions in elementary school are relatively rare: a 0.01 increase in suspensions constitutes a $19 \%$ increase in suspensions from the sample mean.

Columns 2-4 of table 6 augment the model estimated in column 1 to allow the effect of having an other-race teacher to vary by students' gender and race. Consistent with the results for student absences, the male and other-race interaction terms in columns 2 and 3 are positive but 
statistically insignificant, suggesting that the other-race effect is marginally larger for both male and nonwhite students. Column 4 of table 6 further extends the model to allow the racial mismatch effect to vary by student gender and race simultaneously. The male-nonwhite triple interaction term is positive, relatively large in magnitude, and statistically significant. This indicates that on average, relative to white females assigned to nonwhite teachers, nonwhite males assigned to white teachers experience 0.035 more suspensions per year. The average partial effect of having white teacher for nonwhite male students is 0.03 suspensions, a more than $20 \%$ increase in annual suspensions.

The number of suspensions is an appealing measure of student conduct in that the number of suspensions likely approximates the number of severe behavioral incidents. However, students who are suspended are rare in elementary school and, by definition, students who experience multiple suspensions in a given year are rarer still. Moreover, the extensive margin (i.e., whether a student is ever suspended during the course of the school year) may be more policy and developmentally relevant, given the discrete disruption associated with even a single incident that leads to a suspension. Thus, columns 5-8 of table 6 repeat the analysis of the relationship between student-teacher racial mismatch and student suspensions using a binary indicator equal to one if the student was ever suspended during the academic year, and zero otherwise.

The baseline estimate reported in column 5 of table 6 shows that being assigned to an other-race teacher increases the likelihood that a student is ever suspended by half of a percentage point. Again, though the point estimate is small in magnitude, it represents a $15 \%$ increase in the baseline probability that an elementary school student is suspended in a given year. Like the results for total suspensions, columns 6 and 7 show that the impact of an otherrace teacher on the likelihood of being suspended at least once during the academic year is larger 
for male and nonwhite students, respectively, though these differences are not statistically significant at traditional confidence levels. Finally, and again consistent with the results for total suspensions reported in column 4, column 8 of table 6 shows that the impact of student-teacher racial mismatch on the probability that a student is ever suspended during a given academic year is almost entirely driven by nonwhite male students in classrooms taught by white teachers. Again, the statistically significant point estimate of about 0.01 is practically significant as well, which amounts to approximately doubling the likelihood that nonwhite males are suspended at least one time during a given academic year.

\section{Conclusions and Discussion}

The results provide strong evidence of a causal relationship between student-teacher racial mismatch and student absenteeism and suspensions, as predicted by representative bureaucracy theory. Our within-classroom analysis of the impact of racial mismatch at the student-teacher level finds modest, positive, statistically significant effects of racial mismatch on both absenteeism and suspensions, regardless of how absenteeism and propensity to be suspended are measured. Despite the modest effect sizes for student absences, these estimates provide the clearest evidence to date that representative bureaucracy theory correctly emphasizes the importance of comprehensive representation among street-level bureaucrats for effective governance. Moreover, the modest absolute increase in chronic absenteeism reflects a substantive increase of $3.3 \%$ in the likelihood a student will be chronically absent. As previously noted, chronic absenteeism has particularly strong negative effects on long-run student success and evidence suggests that reducing chronic absenteeism alone can yield significant reductions in socio-demographic achievement gaps (Balfanz \& Byrnes, 2012). Of course, student absenteeism 
and suspensions are only two observable dimensions along which representation likely affects teacher-parent interactions and student educational outcomes. As Grissom et al. (2015) rightly point out, future research on students' educational outcomes and the relationship between school staff and parents would benefit from the application of insights from representative bureaucracy theory to develop a more complete picture of the dynamics operating in public school systems. Because elementary school students' absences at least partially reflect parental decisions, our results underscore the importance of representation among street-level bureaucrats in building and sustaining the support for public organizations necessary for equitably carrying out the goals and missions set for public organizations.

The effects of student-teacher racial mismatch on student suspensions are even larger than those on student absences. Suspensions are particularly interesting in this case because they characterize both the relationship a teacher has with students and the discretion a teacher exercises in the "sentencing" process following an incident. The former captures elements of passive representation while the latter is more associated with active representation. While the current study stops short of disentangling these two mechanisms, the results nonetheless provide strong evidence that representation among teachers matters at the classroom level. Students with racially mismatched teachers experienced a $20 \%$ increase in suspensions, driven primarily by the response of nonwhite male students to white classroom teachers. Further, students with racially mismatched teachers experienced a 15\% increase in the likelihood of being suspended at least once during the academic year. These sizable effects underscore the likelihood that some combination of passive and active representation at the classroom level affects socially, academically, and developmentally important student outcomes. 
Together, student suspensions and absences provide a snapshot of outcomes that are likely shaped by the relationships that teachers form with students in their classrooms and with students' parents more generally. Students who miss instructional time, whether due to absence or suspension, fall behind their peers and require additional effort, as well as support from teachers and parents, to catch up. Student-teacher demographic mismatch has a positive impact on both absences and suspensions, which suggests that some combination of passive and active representation occurs in the classroom. The evidence of a casual-link between student-teacher demographic mismatch and student suspensions and absences presented here provides novel, strong support for representative bureaucracy theory, which predicts that demographic alignment among street-level bureaucrats and the citizens they serve cultivates a better relationship for providing public services. These effects, estimated at the individual-level, provide the strongest evidence to date that both passive and active representation play important roles in the administration of effective public organizations.

Finally, this paper makes a methodological contribution to the fields of public administration and public management. Exploiting similar two-way fixed effects (FE) strategies would likely prove fruitful in future research examining the effects of demographic mismatch and representation on public sector employee and constituent behaviors and outcomes in other contexts. For example, similar empirical approaches could be applied to administrative data to study how representation affects sentencing and arrest decisions in court cases and citizen-police interactions, and how manager-employee demographic mismatch affects the productivity, turnover decisions, and morale of public sector employees. Future work might also investigate whether the micro (street) level effects of racial mismatch observed in the current study vary with organizational (school) level characteristics such as size, diversity, and overall performance. 


\section{References}

Abowd, J.M., Kramarz, F., Margolis, D.N., 1999. High wage workers and high wage firms. Econometrica, 67(2), 251-333.

Abowd, J. M., \& Kramarz, F. 1999. The analysis of labor markets using matched employeremployee data. Handbook of Labor Economics Vol. 3, 2629-2710.

Abowd, J.M., Creecy, R.H., Kramarz, F., 2002. Computing Person and firm Effects using Linked Longitudinal Employer-employee Data. Technical Paper No. 2002-06, Longitudinal EmployerHousehold Dynamics, Center for Economic Studies, U.S. Census Bureau.

Alexander, KL, DR Entwisle, and CS Horsey. 1997. From First Grade Forward: Early Foundations of High School Dropout. Sociology of Education, 70(2), 87-107.

Arcia, E. 2006. Achievement and enrollment status of suspended students. Education and Urban Society, 38, 359-369.

Arcidiacono, P., Foster, G., Goodpaster, N., \& Kinsler, J. 2012. Estimating spillovers using panel data, with an application to the classroom. Quantitative Economics, 3(3), 421-470.

Aucejo, Esteban M., and Teresa Foy Romano. 2013. Assessing the effect of school days and absences on test score performance. CFP Discussion Paper No. 1302.

Balfanz, Robert, and Vaughan Byrnes. 2012. Chronic Absenteeism: Summarizing What We Know from Nationally Available Data. Baltimore: Johns Hopkins University Center for Social Organization of Schools.

Bradbury, M, and JE Kellough. 2010. Representative Bureaucracy: Assessing the Evidence on Active Representation. The American Review of Public Administration, 41(2), 157-167.

Bradshaw, CP, MM Mitchell, LM O’Brennan, and PJ Leaf. 2010. Multi-level exploration of factors contributing to the overrepresentation of black students in office disciplinary referrals. Journal of Educational Psychology, 102(2), 508-520.

Burgess, S, and E Greaves. 2013. Test Scores, Subjective Assessment, and Stereotyping of Ethnic Minorities. Journal of Labor Economics, 31(3), 535-576.

Burstein, Leigh. 1980. The Analysis of Multilevel Data in Educational Research and Evaluation. Review of Research in Education, 8, 158-233.

Casteel, CA 1998. Teacher-Student Interactions and Race in Integrated Classrooms. The Journal of Educational Research, 92(2), 115-120.

Clotfelter, C, HF Ladd, JL Vigdor, and J Wheeler. 2006. High-Poverty Schools and the Distribution of Teachers and Principals. North Carolina Law Review, 85, 1346-1379.

Clotfelter, CT, HF Ladd, and JL Vigdor. 2005. Who Teaches Whom? Race and the Distribution of Novice Teachers. Economics of Education Review, 24, 377-392.

. 2006. "Teacher-Student Matching and the Assessment of Teacher Effectiveness." The Journal of Human Resources, 41(4), 778-820. 
Cornwell, C, DB Mustard, and Van J Parys. 2013. Noncognitive Skills and the Gender Disparities in Test Scores and Teacher Assessments: Evidence from Primary School. The Journal of Human Resources, 48(1), 236-264.

Correia, S. 2015. Stata module for linear and instrumental-variable/GMM regression absorbing multiple levels of fixed effects. https://ideas.repec.org/c/boc/bocode/s457874.html

Costenbader, V, and S Markson. 1998. School suspension: A study with secondary school students. Journal of School Psychology, 36(1), 59-82.

Dee, TS. 2004. Teachers, Race, and Student Achievement in a Randomized Experiment. The Review of Economics and Statistics, 86(1), 195-210.

- 2005. A Teacher like Me: Does Race, Ethnicity, or Gender Matter? The American Economic Review, 95(2), 158-165.

- 2007. Teachers and the Gender Gaps in Student Achievement. Journal of Human Resources, 42(3), 528-554.

Dolan, J, and Rosenbloom David. 2003. Representative Bureaucracy: Classic Readings and Continuing Controversies. Armonk: M.E. Sharpe, Inc.

Egalite, AJ, B Kisida, and MA Winters. 2015. Representation in the Classroom: The Effect of Own-Race Teachers on Student Achievement. Economics of Education Review, 45, 44-52.

Ehrenberg, RG and DJ Brewer. 1994. Do School and Teacher Characteristics Matter? Evidence from High School and beyond. Economics of Education Review, 13(1), 1-17.

Ensminger, ME, and AL Slusarcick. 1992. Paths to High School Graduation or Dropout: A Longitudinal Study of a First-Grade Cohort. Sociology of Education, 65(2), 95-113.

Epstein, JL and SB Sheldon. 2002. Present and Accounted for: Improving Student Attendance through Family and Community Involvement. The Journal of Educational Research, 95(5), 308318.

Fairlie, RW, F Hoffman, and P Oreopoulos. 2014. A community college instructor like me: Race and ethnicity interactions in the classroom. American Economic Review, 104(8), 2567-2591.

Ferguson, Ronald F. 2003. Teachers' perceptions and expectations and the black-white test score gap. Urban Education, 38(4), 460-507.

Figlio, D. 2006. Testing, crime and punishment. Journal of Public Economics, 90(4), 837-851.

Finn, JD. 1989. Withdrawing from School. Review of Educational Research, 59(2), 117-142.

Gade, DM, and VM Wilkins. 2013. Where did you serve? Veteran identity, representative bureaucracy, and vocational rehabilitation. Journal of Public Administration Research and Theory, 23, 267-288.

Gaure, S. 2013. OLS with multiple high dimensional category variables. Computational Statistics \& Data Analysis, 66, 8-18.

Gershenson, S. 2015. Linking Teacher Quality, Student Attendance, and Student Achievement. Forthcoming, Education Finance and Policy. DOI: 10.1162/EDFP_a_00180 
Gershenson, S., Holt, S. B., and Papageorge, N. W. 2015. Who Believes in Me? The Effect of Student-Teacher Demographic Match on Teacher Expectations. IZA Discussion Paper No. 9202.

Goodman, J. 2014. Flaking out: Student absences and snow days as disruptions of instructional time. National Bureau of Economic Research Working Paper No. w20221.

Gottfried, MA. 2009. Excused versus Unexcused: How Student Absences in Elementary School Affect Academic Achievement. Educational Evaluation and Policy Analysis, 31(4), 392-415.

Gregory, James F. 1995. The Crime of Punishment: Racial and gender disparities in the use of corporal punishment in U.S. public schools. The Journal of Negro Education, 64(4), 454-462.

Gregory, A, and RS Weinstein. 2008. The discipline gap and the discipline gap: Two sides of the same coin? Educational Researcher, 39, 59-68.

Gregory, A, RJ Skiba, and PA Noguera. 2010. The Achievement Gap and the Discipline Gap: Two Sides of the Same Coin? Educational Researcher, 39(1), 59-68.

Grissom, JA, EC Kern, and LA Rodriguez. 2015. The "Representative Bureaucracy" in education: Educator workforce diversity, policy outputs, and outcomes for disadvantaged students. Educational Researcher, 44(3), 185-192.

Guarino, GM, MD Reckase, and JM Wooldridge. 2014. Can Value-Added Measures of Teacher Performance Be Trusted? Education, Finance, and Policy, 10(1), 117-156.

Guimarães, P., and Portugal, P. 2010. A simple feasible procedure to fit models with highdimensional fixed effects. Stata Journal, 10(4), 628.

Hanushek, EA and SG Rivkin. 2009. Harming the Best: How Schools Affect the Black-white Achievement Gap. Journal of Policy Analysis and Management, 28(3), 366-393.

Hanushek, EA, SG Rivkin, and LL Taylor. 1996. Aggregation and the Estimated Effects of School Resources. The Review of Economics and Statistics, 78(4), 611-627.

Hoffmann, F., and Oreopoulos, P. 2009. A professor like me: The influence of instructor gender on college achievement. Journal of Human Resources, 44(2), 479-494.

Jackson, C. Kirabo. 2013. Non-cognitive ability, test scores, and teacher quality: Evidence from 9th grade teachers in North Carolina. NBER Working Paper No. 18624.

Jacob, BA. 2002. Where the boys aren't: non-cognitive skills, returns to school, and the gender gap in higher education. Economics of Education Review, 21, 589-598.

Jennings, Jennifer L., and Thomas A. DiPrete. 2010. Teacher effects on social and behavioral skills in early elementary school. Sociology of Education 83(2):135-159.

Keiser, LR. 2010. "Representative Bureaucracy." In The Oxford Handbook of American Bureaucracy, edited by Durant Robert F, 714-37. New York: Oxford University Press.

Keiser, LR, VM Wilkins, and KJ Meier. 2002. Lipstick and Logarithms: Gender, Institutional Context, and Representative Bureaucracy. American Political Science Review, 96(3), 553-564. 
Kelly, S. 2012. Understanding teacher effects: Market versus process models of educational improvement. In Assessing Teacher Quality, edited by S. Kelly, pp. 7-32. New York: Teachers College Press

Kingsley, D. 1944. Representative Bureaucracy. Yellow Springs: Antioch Press.

Kinsler, J. 2011. Understanding the black-white school discipline gap. Economics of Education Review, 30, 1370-1383.

Krislov, S. 1974. Representative Bureaucracy. Englewood Cliffs: Prentice-Hall.

Ladd, HF, and LC Sorensen. 2014. Returns to teacher experience: Student achievement and motivation in middle school. Center for Analysis of Longitudinal Data in Education Research Working Paper 112.

Lavy, V. 2008. Do Gender Stereotypes Reduce Girls’ or Boys' Human Capital Outcomes? Evidence from a Natural Experiment. Journal of Public Economics, 92, 2083-2105.

Long, NE. 1952. Bureaucracy and Constitutionalism. American Political Science Review, 46(3), 808-818.

Losen D, and R Skiba. 2010. Suspended education: Urban middle schools in crisis.

Montgomery, AL: Southern Poverty Law Center.

Marschall, MJ, and AVS Ruhil. 2007. Substantive Symbols: The Attitudinal Dimension of Black Political Incorporation in Local Government. American Journal of Political Science, 51(1), 1733.

Meier, KJ. 1975. Representative Bureaucracy: An Empirical Analysis. American Political Science Review, 69(2), 526-542.

Meier, KJ. 1993. Latinos and Representative Bureaucracy: Testing the Thompson and Henderson Hypotheses. Journal of Public Administration Research and Theory, 3(4), 393-414.

Meier, KJ, and J Nicholson-Crotty. 2006. Gender, Representative Bureaucracy, and Law Enforcement: The Case of Sexual Assault. Public Administration Review, 850-860.

Meier, KJ, and J Stewart. 1992. The Impact of Representative Bureaucracies: Educational Systems and Public Policies. The American Review of Public Administration, 22(3), 157-171.

Meier, KJ, J Stewart, and RE England. 1989. Race, Class, and Education: The Politics of Second-Generation Discrimination. Madison, WI: University of Wisconsin Press.

Mendez, LMR. 2003. Predictors of suspension and negative school outcomes: A longitudinal investigation. New Directions for Youth Development, 99, 17-33.

Mendez, LMR, and HM Knoff. 2003. Who gets suspended from school and why: A demographic analysis of schools and disciplinary infractions in a large school district. Education and Treatment of Children, 26(1), 30-51.

Mendez, LMR, HM Knoff, and JM Ferron. 2002. School demographic variables and out-ofschool suspension rates: A quantitative and qualitative analysis of a large, ethnically diverse school district. Psychology in the School, 39(3), 259-277. 
Mittag, N. 2012. New methods to estimate models with large sets of fixed effects with an application to matched employer-employee data from Germany. FDZ-Methodenreport.

Monk, DH, and MA Ibrahim. 1984. Patterns of Absence and Pupil Achievement. American Educational Research Journal, 21(2), 295-310.

Morrissey, TW, L Hutchison, and A Winsler. 2014. Family Income, School Attendance, and Academic Achievement in Elementary School. Developmental Psychology, 50(3), 741-753.

Mosher, F. 1968. Democracy and the Public Service. New York: Oxford University Press.

Musser, Martha Philbeck. 2011. Taking attendance seriously: How school absences undermine student and school performance in New York City. New York: Campaign the Fiscal Equity.

NCES. 2006. The Condition of Education. Washington, DC: U.S. Department of Education.

Ouazad, A. 2014. Assessed by a Teacher Like Me: Race and Teacher Assessments. Education, Finance, and Policy, 9(3), 334-372.

Pitts, DW. 2007. Representative Bureaucracy, Ethnicity, and Public Schools Examining the Link Between Representation and Performance. Administration \& Society, 39(4), 497-526.

Ready, Douglas D. 2010. Socioeconomic Disadvantage, School Attendance, and Early Cognitive Development: The Differential Effects of School Exposure. Sociology of Education, 83(4), 271286.

Riccucci, NM, GC Van Ryzin, and CF Lavena. 2014. Representative Bureaucracy in Policing: Does it increase perceived legitimacy? Journal of Public Administration Research and Theory, 24, 537-551.

Rivkin, S. G., Hanushek, E. A., and Kain, J. F. 2005. Teachers, schools, and academic achievement. Econometrica, 417-458.

Rocque, M. 2010. Office discipline and student behaviors: Does race matter? American Journal of Education, 116(4), 557-581.

Romero, M, and Lee, YS. 2008. The Influence of Maternal and Family Risk on Chronic Absenteeism in Early Schooling. National Center for Children in Poverty.

Rosenbloom, DH, and JG Featherstonhaugh. 1977. Passive and Active Representation in the Federal Service: A Comparison of Blacks and Whites. Social Science Quarterly, 57(4), 873-882.

Rumberger, RW. 1995. Dropping out of Middle School: A Multilevel Analysis of Students and Schools. American Educational Research Journal, 32(3), 583-615.

Selden, S. 1997. The Promise of Representative Bureaucracy: Diversity and Responsiveness in a Government Agency. Armonk: M.E. Sharpe, Inc.

Sheats, D, and GE Dunkleberger. 1979. A Determination of the Principal's Effect in SchoolInitiated Home Contacts Concerning Attendance of Elementary School Students. The Journal of Educational Research, 72(6), 310-312.

Skiba, RJ, CG Chung, M Trachok, TL Baker, A Sheya, and RL Hughes. 2014. Parsing disciplinary disproportionality: Contributions of infraction, student, and school characteristics to 
out-of-school suspension and expulsion. American Educational Research Journal, 51(4), 640670.

Skiba, RJ, RH Horner, CG Chung, MK Rausch, SL May, T Tobin. 2011. Race is not neutral: A national investigation of African American and Latino disproportionality in school discipline. School Psychology Review, 40(1), 85-107.

Skiba, RJ, RS Michael, AC Nardo, and R Peterson. 2002. The color of discipline: Sources of racial and gender disproportionality in school punishment. The Urban Review, 34, 317-342.

Steele, Claude M. (1997). A threat in the air: How stereotypes shape intellectual identity and performance. American Psychologist, 52(6), 613-629.

Theobald, NA, and DP Haider-Markel. 2009. Race, Bureaucracy, and Symbolic Representation: Interactions between Citizens and Police. Journal of Public Administration Research and Theory, 19, 409-426.

Thompson, FJ. 1976. Minority Groups in Public Bureaucracies Are Passive and Active Representation Linked? Administration \& Society, 8(2), 201-226.

United States Department of Education, Office for Civil Rights. 2014. Data Snapshot: School Discipline. Civil Rights Data Collection, Issue Brief No. 1, 1-24.

Van Riper, PP. 1958. History of the United States Civil Service. Evanston, IL: Row, Peterson, \& Company.

Wilkins, VM, and BN Williams. 2008. Black or blue: Racial profiling and representative bureaucracy. Public Administration Review, 68, 654-664.

- 2009. Representing blue: Representative bureaucracy and racial profiling in the Latino community. Administration \& Society, 40, 775-798. 
Table 1. Analytic Sample Summary Statistics

\begin{tabular}{|c|c|c|c|c|c|}
\hline Sample: & $\begin{array}{c}\text { All Students } \\
\text { (1) }\end{array}$ & $\begin{array}{l}\text { White } \\
\text { Students } \\
\text { (2) }\end{array}$ & $\begin{array}{l}\text { Non-White } \\
\text { Students } \\
\text { (3) }\end{array}$ & $\begin{array}{c}\text { Male } \\
\text { Students } \\
\text { (4) }\end{array}$ & $\begin{array}{c}\text { Female } \\
\text { Students } \\
\quad(5)\end{array}$ \\
\hline Absences & $\begin{array}{c}7.084 \\
(6.330)\end{array}$ & $\begin{array}{c}7.402 \\
(6.259)\end{array}$ & $\begin{array}{c}6.671 \\
(6.398)\end{array}$ & $\begin{array}{c}7.133 \\
(6.389)\end{array}$ & $\begin{array}{c}7.031 \\
(6.267)\end{array}$ \\
\hline Chronic Absence & 0.060 & 0.061 & 0.059 & 0.062 & 0.058 \\
\hline Excused Abs. & $\begin{array}{c}4.292 \\
(4.806)\end{array}$ & $\begin{array}{c}4.922 \\
(4.964)\end{array}$ & $\begin{array}{c}3.476 \\
(4.463)\end{array}$ & $\begin{array}{c}4.292 \\
(4.824)\end{array}$ & $\begin{array}{c}4.292 \\
(4.786)\end{array}$ \\
\hline Unexcused Abs. & $\begin{array}{c}2.566 \\
(3.707)\end{array}$ & $\begin{array}{c}2.254 \\
(3.310)\end{array}$ & $\begin{array}{c}2.969 \\
(4.131)\end{array}$ & $\begin{array}{c}2.612 \\
(3.750)\end{array}$ & $\begin{array}{c}2.518 \\
(3.661)\end{array}$ \\
\hline Total suspensions & $\begin{array}{c}0.057 \\
(0.402)\end{array}$ & $\begin{array}{c}0.032 \\
(0.287)\end{array}$ & $\begin{array}{c}0.089 \\
(0.512)\end{array}$ & $\begin{array}{c}0.089 \\
(0.512)\end{array}$ & $\begin{array}{c}0.022 \\
(0.231)\end{array}$ \\
\hline Days suspended & $\begin{array}{c}0.096 \\
(0.862)\end{array}$ & $\begin{array}{c}0.048 \\
(0.653)\end{array}$ & $\begin{array}{c}0.158 \\
(1.070)\end{array}$ & $\begin{array}{c}0.152 \\
(1.116)\end{array}$ & $\begin{array}{c}0.037 \\
(0.454)\end{array}$ \\
\hline Ever suspended & 0.033 & 0.020 & 0.050 & 0.050 & 0.015 \\
\hline ISS & $\begin{array}{c}0.014 \\
(0.191)\end{array}$ & $\begin{array}{c}0.010 \\
(0.156)\end{array}$ & $\begin{array}{c}0.019 \\
(0.229)\end{array}$ & $\begin{array}{c}0.022 \\
(0.240)\end{array}$ & $\begin{array}{c}0.006 \\
(0.120)\end{array}$ \\
\hline OSS & $\begin{array}{c}0.043 \\
(0.322)\end{array}$ & $\begin{array}{c}0.021 \\
(0.213)\end{array}$ & $\begin{array}{c}0.070 \\
(0.421)\end{array}$ & $\begin{array}{c}0.067 \\
(0.412)\end{array}$ & $\begin{array}{c}0.016 \\
(0.180)\end{array}$ \\
\hline Other race teacher & 0.407 & 0.062 & 0.854 & 0.405 & 0.409 \\
\hline \multicolumn{6}{|c|}{ Student Demographics } \\
\hline Male & 0.513 & 0.516 & 0.510 & 1.000 & 0.000 \\
\hline White & 0.564 & 1.000 & 0.000 & 0.567 & 0.562 \\
\hline Non-white & 0.436 & 0.000 & 1.000 & 0.433 & 0.438 \\
\hline Asian & 0.018 & 0.000 & 0.042 & 0.018 & 0.019 \\
\hline Native Amer. & 0.017 & 0.000 & 0.037 & 0.016 & 0.017 \\
\hline Black & 0.251 & 0.000 & 0.574 & 0.250 & 0.251 \\
\hline Hispanic & 0.114 & 0.000 & 0.261 & 0.114 & 0.114 \\
\hline Multi-racial & 0.043 & 0.000 & 0.094 & 0.042 & 0.044 \\
\hline
\end{tabular}

Notes: $\mathrm{N}=2,124,022$ student-years. (Suspension data observed for $\mathrm{N}=989,985$ ). Standard Deviations of non-binary variables are reported in parentheses. Chronic absence is a binary indicator equal to 1 if the student was absence 18 or more times during the academic year, and 0 otherwise. Ever suspended is a binary indicator equal to 1 if the student was suspended from school at least once during the academic year, and 0 otherwise. ISS and OSS refer to In and Out of school suspensions, respectively. 
Table 2. Descriptive OLS Regressions

\begin{tabular}{|c|c|c|c|c|c|}
\hline Dependent Variable: & $\begin{array}{c}\text { Other-race } \\
\text { Teacher } \\
\text { (1) }\end{array}$ & $\begin{array}{c}\text { Absences } \\
(2)\end{array}$ & $\begin{array}{c}\text { Chronic } \\
\text { Absence } \\
(3)\end{array}$ & $\begin{array}{c}\text { Total } \\
\text { Suspensions } \\
(4) \\
\end{array}$ & $\begin{array}{c}\text { Ever } \\
\text { Suspended } \\
(5) \\
\end{array}$ \\
\hline \multicolumn{6}{|c|}{ A. Crude race groupings } \\
\hline Male Student & $\begin{array}{c}-0.001 \\
(0.000)^{*}\end{array}$ & $\begin{array}{c}0.109 \\
(0.013)^{* * *}\end{array}$ & $\begin{array}{c}0.003 \\
(0.000)^{* * *}\end{array}$ & $\begin{array}{c}0.067 \\
(0.003)^{* * *}\end{array}$ & $\begin{array}{c}0.036 \\
(0.001)^{* * *}\end{array}$ \\
\hline White Student & (omitted) & & & & \\
\hline Nonwhite Student & $\begin{array}{c}0.796 \\
(0.006) * * *\end{array}$ & $\begin{array}{c}-0.713 \\
(0.039)^{* * *}\end{array}$ & $\begin{array}{l}-0.001 \\
(0.001)\end{array}$ & $\begin{array}{c}0.057 \\
(0.004)^{* * *}\end{array}$ & $\begin{array}{c}0.031 \\
(0.002)^{* * *}\end{array}$ \\
\hline Adj. $\mathrm{R}^{2}$ & 0.641 & 0.003 & $<0.001$ & 0.012 & 0.017 \\
\hline \multicolumn{6}{|c|}{ B. Detailed race groupings } \\
\hline Male Student & $\begin{array}{c}-0.001 \\
(0.000)^{* *}\end{array}$ & $\begin{array}{c}0.109 \\
(0.013)^{* * *}\end{array}$ & $\begin{array}{c}0.003 \\
(0.000)^{* * *}\end{array}$ & $\begin{array}{c}0.067 \\
(0.003)^{* * *}\end{array}$ & $\begin{array}{c}0.036 \\
(0.001)^{* * *}\end{array}$ \\
\hline White Student & (omitted) & & & & \\
\hline Asian Student & $\begin{array}{c}0.897 \\
(0.004)^{* * *}\end{array}$ & $\begin{array}{c}-2.018 \\
(0.063)^{* * *}\end{array}$ & $\begin{array}{c}-0.022 \\
(0.002)^{* * *}\end{array}$ & $\begin{array}{c}-0.020 \\
(0.002)^{* * *}\end{array}$ & $\begin{array}{c}-0.010 \\
(0.001)^{* * *}\end{array}$ \\
\hline Black Student & $\begin{array}{c}0.587 \\
(0.056) * * *\end{array}$ & $\begin{array}{c}1.195 \\
(0.132)^{* * *}\end{array}$ & $\begin{array}{c}0.036 \\
(0.004)^{* * *}\end{array}$ & $\begin{array}{c}0.032 \\
(0.006) * * *\end{array}$ & $\begin{array}{c}0.019 \\
(0.003)^{* * *}\end{array}$ \\
\hline Hispanic Student & $\begin{array}{c}0.698 \\
(0.008)^{* * *}\end{array}$ & $\begin{array}{c}-0.682 \\
(0.050)^{* * *}\end{array}$ & $\begin{array}{c}0.003 \\
(0.001)^{* *}\end{array}$ & $\begin{array}{c}0.096 \\
(0.006)^{* * *}\end{array}$ & $\begin{array}{c}0.050 \\
(0.002)^{* * *}\end{array}$ \\
\hline Multiracial Student & $\begin{array}{c}0.906 \\
(0.003)^{* * *}\end{array}$ & $\begin{array}{c}-0.982 \\
(0.048)^{* * *}\end{array}$ & $\begin{array}{c}-0.012 \\
(0.001)^{* * *}\end{array}$ & $\begin{array}{l}-0.002 \\
(0.002)\end{array}$ & $\begin{array}{c}0.000 \\
(0.001)\end{array}$ \\
\hline Adj. $R^{2}$ & 0.644 & 0.007 & 0.001 & 0.018 & 0.024 \\
\hline $\mathrm{N}$ & $2,124,022$ & $2,124,022$ & $2,124,022$ & 989,985 & 989,985 \\
\hline
\end{tabular}

Notes: Standard errors are clustered by school. Chronic absence is a binary indicator equal to 1 if the student was absence 18 or more times during the academic year, and 0 otherwise. Ever suspended is a binary indicator equal to 1 if the student was suspended from school at least once during the academic year, and 0 otherwise. $* * * \mathrm{p}<0.01$, $* * \mathrm{p}<0.05$, and $* \mathrm{p}<0.1$. 
Table 3: Sorting Test Estimates

\begin{tabular}{lcccccc}
\hline Dependent Variable: & Male & $\begin{array}{c}\text { Lagged } \\
\text { Unexcused } \\
\text { Absences } \\
(2)\end{array}$ & $\begin{array}{c}\text { Lagged } \\
\text { Chronic } \\
\text { Absence } \\
(3)\end{array}$ & $\begin{array}{c}\text { Lagged } \\
\text { Ever } \\
\text { Suspended } \\
(4)\end{array}$ & $\begin{array}{c}\text { Math } \\
\text { Learning } \\
\text { Disability } \\
(5)\end{array}$ & $\begin{array}{c}\text { Reading } \\
\text { Learning } \\
\text { Disability } \\
(6)\end{array}$ \\
\hline A. School, Grade, and Year FE Estimates & & & & \\
\hline Black student & -0.003 & 0.254 & 0.033 & -0.008 & 0.007 & 0.003 \\
& $(0.002)^{*}$ & $(0.027)^{* * *}$ & $(0.002)^{* * *}$ & $(0.001)^{* * *}$ & $(0.002)^{* * *}$ & $(0.002)^{*}$ \\
Black teacher & 0.005 & 0.064 & 0.002 & 0.000 & -0.001 & 0.013 \\
& $(0.002)^{* *}$ & $(0.039)$ & $(0.002)$ & $(0.002)$ & $(0.005)$ & $(0.005)^{* *}$ \\
Interaction Term $(\pi)$ & -0.002 & -0.052 & 0.004 & 0.004 & 0.001 & -0.001 \\
& $(0.003)$ & $(0.054)$ & $(0.003)$ & $(0.003)$ & $(0.004)$ & $(0.004)$ \\
N & 169,736 & 79,909 & 58,610 & 95,110 & 89,015 & 89,015 \\
& & & & & \\
B. School-by-grade-by-year FE estimates & & & & \\
\hline Black student & -0.003 & 0.233 & 0.034 & -0.008 & 0.005 & 0.001 \\
& $(0.002)^{*}$ & $(0.026)^{* * *}$ & $(0.002)^{* * *}$ & $(0.001)^{* * *}$ & $(0.002)^{* * *}$ & $(0.002)$ \\
Black teacher & 0.005 & 0.063 & 0.001 & -0.002 & 0.002 & 0.011 \\
& $(0.002)^{* *}$ & $(0.037)^{*}$ & $(0.002)$ & $(0.002)$ & $(0.005)$ & $(0.006)^{* *}$ \\
Interaction Term $(\pi)$ & -0.002 & -0.034 & 0.004 & 0.004 & 0.001 & -0.000 \\
& $(0.003)$ & $(0.052)$ & $(0.003)$ & $(0.003)$ & $(0.003)$ & $(0.004)$ \\
N & 169,736 & 79,909 & 58,610 & 95,110 & 89,015 & 89,015 \\
\hline
\end{tabular}

Notes: Bold interaction terms are the interaction between the black teacher and black student mean indicators, which constitute the sorting test described by equation (2) in the text. Standard errors are clustered by school. $* * * \mathrm{p}<0.01, * * \mathrm{p}<0.05$, and $* \mathrm{p}<0.1$. 
Table 4. Effect of Other-Race Teachers on Student Absences

\begin{tabular}{lcccc}
\hline Outcome: & Absences & Chronic Absence & Excused Absences & $\begin{array}{c}\text { Unexcused } \\
\text { Absences } \\
\end{array}$ \\
& $(1)$ & $(2)$ & $(3)$ & $(4)$ \\
\hline Other-Race & 0.042 & 0.002 & -0.001 & 0.059 \\
& $(0.025)^{*}$ & $(0.001)^{* *}$ & $(0.031)$ & $(0.025)^{* *}$ \\
N & & & & \\
Adj. $\mathrm{R}^{2}$ & $2,124,022$ & $2,124,022$ & $1,400,434$ & $1,400,434$ \\
\hline
\end{tabular}

Notes: All models condition on both student and classroom fixed effects. Both sets of fixed effects are jointly statistically significant in all models. Standard errors are clustered by school. Chronic absence is a binary indicator equal to 1 if the student was absence 18 or more times during the academic year, and 0 otherwise. $* * * \mathrm{p}<0.01$, ** $\mathrm{p}<0.05$, and $* \mathrm{p}<0.1$. 
Table 5. Heterogeneous Effects of Racial Mismatch on Student Absences

\begin{tabular}{|c|c|c|c|c|c|c|c|c|c|}
\hline \multirow[t]{2}{*}{ Outcome: } & \multicolumn{3}{|c|}{ Absences } & \multicolumn{3}{|c|}{ Chronic Absence } & \multicolumn{3}{|c|}{ Unexcused Absences } \\
\hline & (1) & $(2)$ & (3) & (4) & $(5)$ & (6) & $(7)$ & $(8)$ & (9) \\
\hline Other-Race (OR) & $\begin{array}{c}0.014 \\
(0.033)\end{array}$ & $\begin{array}{c}0.003 \\
(0.058)\end{array}$ & $\begin{array}{l}-0.012 \\
(0.068)\end{array}$ & $\begin{array}{c}0.002 \\
(0.002)\end{array}$ & $\begin{array}{l}-0.001 \\
(0.003)\end{array}$ & $\begin{array}{l}-0.001 \\
(0.003)\end{array}$ & $\begin{array}{c}0.045 \\
(0.032)\end{array}$ & $\begin{array}{c}0.078 \\
(0.055)\end{array}$ & $\begin{array}{c}0.050 \\
(0.062)\end{array}$ \\
\hline OR $\times$ Male & $\begin{array}{c}0.055 \\
(0.045)\end{array}$ & & $\begin{array}{c}0.027 \\
(0.067)\end{array}$ & $\begin{array}{c}0.001 \\
(0.002)\end{array}$ & & $\begin{array}{c}0.000 \\
(0.003)\end{array}$ & $\begin{array}{c}0.028 \\
(0.041)\end{array}$ & & $\begin{array}{c}0.054 \\
(0.058)\end{array}$ \\
\hline Male APE & $\begin{array}{c}0.069 \\
(0.034)^{* *}\end{array}$ & & & $\begin{array}{c}0.003 \\
(0.002)^{*}\end{array}$ & & & $\begin{array}{c}0.073 \\
(0.033)^{* *}\end{array}$ & & \\
\hline OR $\times$ Nonwhite & & $\begin{array}{c}0.075 \\
(0.098)\end{array}$ & $\begin{array}{c}0.050 \\
(0.108)\end{array}$ & & $\begin{array}{c}0.007 \\
(0.004)\end{array}$ & $\begin{array}{c}0.006 \\
(0.005)\end{array}$ & & $\begin{array}{l}-0.035 \\
(0.094)\end{array}$ & $\begin{array}{l}-0.012 \\
(0.101)\end{array}$ \\
\hline Nonwhite APE & & $\begin{array}{c}0.078 \\
(0.052)\end{array}$ & & & $\begin{array}{c}0.005 \\
(0.002)^{* *}\end{array}$ & & & $\begin{array}{c}0.043 \\
(0.052)\end{array}$ & \\
\hline OR $\times$ Male $\times$ Nonwhite & & & $\begin{array}{c}0.048 \\
(0.086)\end{array}$ & & & $\begin{array}{l}0.0003 \\
(0.004)\end{array}$ & & & $\begin{array}{l}-0.045 \\
(0.084)\end{array}$ \\
\hline Nonwhite Male APE & & & $\begin{array}{c}0.114 \\
(0.060)^{*}\end{array}$ & & & $\begin{array}{c}0.006 \\
(0.002)^{* *}\end{array}$ & & & $\begin{array}{c}0.047 \\
(0.061)\end{array}$ \\
\hline $\begin{array}{l}\text { Joint significance of } \\
\text { interaction terms }(p)\end{array}$ & & & 0.504 & & & 0.501 & & & 0.792 \\
\hline $\mathrm{N}$ & $2,124,022$ & $2,124,022$ & $2,124,022$ & $2,124,022$ & $2,124,022$ & $2,124,022$ & $1,400,434$ & $1,400,434$ & $1,400,434$ \\
\hline Adj. R2 & 0.596 & 0.596 & 0.596 & 0.383 & 0.383 & 0.383 & 0.591 & 0.591 & 0.591 \\
\hline
\end{tabular}


Table 6. Effects of Racial Mismatch on Student Suspensions

\begin{tabular}{|c|c|c|c|c|c|c|c|c|}
\hline \multirow[t]{2}{*}{ Outcome: } & \multicolumn{4}{|c|}{ Total Suspensions } & \multicolumn{4}{|c|}{ Ever Suspended } \\
\hline & (1) & $(2)$ & (3) & (4) & (5) & (6) & $(7)$ & $\overline{(8)}$ \\
\hline Other-Race (OR) & $\begin{array}{c}0.011 \\
(0.005)^{* *}\end{array}$ & $\begin{array}{c}0.006 \\
(0.005)\end{array}$ & $\begin{array}{c}0.006 \\
(0.009)\end{array}$ & $\begin{array}{c}0.010 \\
(0.009)\end{array}$ & $\begin{array}{c}0.005 \\
(0.002)^{* *}\end{array}$ & $\begin{array}{c}0.002 \\
(0.002)\end{array}$ & $\begin{array}{c}0.002 \\
(0.004)\end{array}$ & $\begin{array}{c}0.003 \\
(0.004)\end{array}$ \\
\hline OR $\times$ Male & & $\begin{array}{c}0.011 \\
(0.008)\end{array}$ & & $\begin{array}{l}-0.008 \\
(0.008)\end{array}$ & & $\begin{array}{c}0.005 \\
(0.004)\end{array}$ & & $\begin{array}{l}-0.002 \\
(0.005)\end{array}$ \\
\hline Male APE & & $\begin{array}{c}0.017 \\
(0.008)^{* *}\end{array}$ & & & & $\begin{array}{c}0.007 \\
(0.003) * *\end{array}$ & & \\
\hline OR $\times$ Nonwhite & & & $\begin{array}{c}0.010 \\
(0.015)\end{array}$ & $\begin{array}{l}-0.008 \\
(0.015)\end{array}$ & & & $\begin{array}{c}0.006 \\
(0.008)\end{array}$ & $\begin{array}{l}-0.001 \\
(0.008)\end{array}$ \\
\hline Nonwhite APE & & & $\begin{array}{c}0.017 \\
(0.010)^{*}\end{array}$ & & & & $\begin{array}{c}0.007 \\
(0.005)\end{array}$ & \\
\hline OR $\times$ Male $\times$ Nonwhite & & & & $\begin{array}{c}0.035 \\
(0.016)^{* *}\end{array}$ & & & & $\begin{array}{c}0.014 \\
(0.008)^{*}\end{array}$ \\
\hline Nonwhite Male APE & & & & $\begin{array}{c}0.030 \\
(0.013)^{* *}\end{array}$ & & & & $\begin{array}{c}0.013 \\
(0.006)^{* *}\end{array}$ \\
\hline $\begin{array}{l}\text { Joint significance of } \\
\text { interaction terms }(p)\end{array}$ & & & & 0.192 & & & & 0.271 \\
\hline Adj. R2 & 0.432 & 0.432 & 0.432 & 0.433 & 0.340 & 0.340 & 0.340 & 0.340 \\
\hline
\end{tabular}

Notes: $\mathrm{N}=989,985$. All models condition on both student and classroom fixed effects. Both sets of fixed effects are jointly statistically significant in all models. Standard errors are clustered by school. Ever suspended is a binary indicator equal to 1 if the student was suspended from school at least once during the academic year, and 0 otherwise. Standard errors for the average partial effects (APE) were computed via the Delta Method. *** $\mathrm{p}<0.01, * * \mathrm{p}<0.05$, and $* \mathrm{p}<0.1$ 